\title{
The Effect of Compression, Stretching, and Cooking Temperature on Free Oil Formation in Mozzarella Curd
}

\author{
M. K. Rowney, ${ }^{*, 1}$ P. Roupas, $†$ M. W. Hickey, ${ }^{\star}$ and D. W. Everett‡ \\ *Institute of Land and Food Resources, \\ University of Melbourne, \\ Victoria 3052 Australia \\ †Food Science Australia, Werribee, \\ Victoria 3030 Australia \\ fDepartment of Food Science, \\ University of Otago, \\ Dunedin 9001 New Zealand
}

\section{ABSTRACT}

The effect of the extent and rate of compression and stretching on free oil formation in Mozzarella cheese curd was investigated at 55,65 , and $75^{\circ} \mathrm{C}$. Confocal laser scanning microscopy was used to determine the maximum cross-sectional diameter, cross-sectional area, elongation factor (maximum divided by minimum cross-sectional diameter), and circularity of fat globules in the cheese curd at the different temperatures, and after stretching or compression. Free oil was not significantly affected by the rate of biaxial compression from 50 to $2000 \mathrm{~mm} / \mathrm{min}$ at $65^{\circ} \mathrm{C}$, the rate of tensile stretching from 1000 to $2500 \mathrm{~mm} / \mathrm{min}$ at $60^{\circ} \mathrm{C}$, or the extent of biaxial compression from 40 to $80 \%$ of the original height at $1000 \mathrm{~mm} / \mathrm{min}$ and $65^{\circ} \mathrm{C}$. Increasing the rate of stretching from 1000 to $2500 \mathrm{~mm} / \mathrm{min}$ increased the elongation factor from 1.91 to 2.61. Crosssectional area, maximum diameter, and circularity were not affected by the rate of biaxial compression. The extent of curd compression had no effect on the milk fat globule size and shape. Increasing the extent of stretching at $60^{\circ} \mathrm{C}$ and at $1000 \mathrm{~mm} / \mathrm{min}$ increased the free oil content (on a fat basis) from $23.8 \%$ (curd stretched by $1.4 \times$ ) to $32.3 \%$ (stretched by $4.6 \times$ ) and the elongation factor of the globules, but did not affect any of the other globule parameters. Increasing the temperature of the cooking-stretching water increased the cross-sectional area, diameter of the globules, and free oil content from $24.1 \%$ at $55^{\circ} \mathrm{C}$ to $34.5 \%$ at $75^{\circ} \mathrm{C}$ for curd compressed to $50 \%$ height at $1000 \mathrm{~mm} / \mathrm{min}$.

(Key words: free oil, cheese curd, cooking, stretching)

Received May 16, 2002

Accepted August 13, 2002.

Corresponding author: David W. Everett; e-mail: d.everett@ otago.ac.nz.

${ }^{1}$ Current address: Murray Goulburn Co-operative Co. Ltd, 140 Dawson St., Brunswick, Victoria, Australia.
Abbreviation key: CLSM = confocal laser scanning microscopy.

\section{INTRODUCTION}

The effect of thermal processing during the cooking and stretching process of Mozzarella cheese manufacture on free oil formation is not well understood. The $\mathrm{pH}$ of curd at stretch, screw speed, stretcher design, temperature of curd and stretching water, and residence time in the cooker and stretcher are all known to play a role in the formation of free oil.

Mozzarella cheese microstructure consists of cavities containing serum phase and fat globules, surrounded by protein strands (Oberg et al., 1993). Some fat globules are embedded in the protein matrix as well as free within cavities (Kindstedt and Guo, 1998). Fat globules that are emulsified, rather than free oil entrapped within voids in the protein matrix, have been reported to contribute to free oil formation (McMahon et al., 1993). The size of the fat globules is directly related to the amount of free oil formed; however, in this study, milk was homogenized, thus coating the fat globules with a new membrane material consisting of casein fragments. Free oil has also been shown to increase in Mozzarella cheese at higher fat levels (Tunick, 1994).

Optimal stretching of Mozzarella curd occurs in the range of $\mathrm{pH} 5.0$ to 5.3, where calcium phosphate is becoming more dissociated and a decrease in the net charge on proteins facilitates an increasing degree of hydrophobic interaction between casein molecules. Curd stretched at $\mathrm{pH} 5.3$ is more structured, as indicated by a higher apparent viscosity immediately after manufacture that continues during the ripening process, compared to Mozzarella curd made from curd stretched at pH 5.0 (Yun et al., 1993).

In a systematic study on the effect of a twin screw cooker-stretcher on Mozzarella cheese functionality, it was observed that cheese made from curd stretched at a 
Table 1. The effect of biaxial compression rate on composition, free oil content, and milk fat globule microstructure of curd compressed to $50 \%$ of the original height at $65^{\circ} \mathrm{C}(\mathrm{n}=5)$.

\begin{tabular}{lcccc}
\hline & \multicolumn{3}{c}{ Biaxial compression rate $(\mathrm{mm} / \mathrm{min})$} & \\
\cline { 2 - 4 } & 50 & 500 & 2000 & Significance \\
\hline Moisture, \% & 43.1 & 43.3 & 43.2 & $\mathrm{NS}$ \\
Fat, \% & 23.3 & 23.0 & 23.2 & $\mathrm{NS}$ \\
Fat in dry matter, \% & 40.9 & 40.6 & 40.9 & $\mathrm{NS}$ \\
Protein, \% & 26.1 & 26.1 & 26.5 & $\mathrm{NS}$ \\
Free oil, \% of curd & 6.1 & 5.9 & 6.0 & $\mathrm{NS}$ \\
Free oil, \% of fat & 26.2 & 25.4 & 25.1 & $\mathrm{NS}$ \\
Cross-sectional area, $\mu \mathrm{m}^{2}$ & 64.2 & 52.0 & 60.2 & $\mathrm{NS}$ \\
Maximum diameter, $\mu \mathrm{m}$ & 10.1 & 9.0 & 9.3 & $\mathrm{NS}$ \\
Circularity & 0.48 & 0.49 & 0.50 & $\mathrm{NS}$ \\
Elongation factor & $1.90^{\mathrm{a}}$ & $1.95^{\mathrm{ab}}$ & $1.75^{\mathrm{b}}$ & $* *$ \\
\hline
\end{tabular}

${ }^{\mathrm{a}, \mathrm{b}}$ Subcolumn means within row and treatment category with different superscripts differ $(P<0.05)$.

${ }^{1}$ Elongation factor $=($ maximum diameter $) /($ minimum diameter $)$.

$* * P<0.01$.

screw speed of $5 \mathrm{rpm}$ had a free oil content significantly higher than cheese made using screw speeds of 12 or 19 rpm (Renda et al., 1997). In contrast, Mozzarella cheese manufactured in a twin-screw extruder, which imparts a higher shear stress than a cooker-stretcher, yields a cheese with no measurable free oil (Apostolopoulos et al., 1994), possibly by altering the distribution of the milk fat globules within the casein matrix. In another study, the milk fat globule distribution in Mozzarella cheese was found to be affected by stretching (Taneya et al., 1992), but the effect on free oil formation was not measured.

The temperature of curd during the stretching step, which is affected by water temperature, mechanical work input and heating time, may impact functional properties of cheese such as shredding and melting. Increasing the stretching temperature of the curd from 57 to $75^{\circ} \mathrm{C}$ has been shown to reduce the elastic properties of Mozzarella cheese (Mulvaney et al., 1997). Temperature and screw speed are important factors in affecting free oil formation, and a balance needs to be achieved between the amount of tearing of the curd by the screw action and the coalescence of the milk fat globules at different temperatures (Mulvaney et al., 1997).

In the present study, the effects of stretching and compression rate, extent of stretching and compression, and temperature on free oil formation were investigated in Mozzarella curd obtained from a commercial manufacturer. The effect of these manufacturing conditions on fat globule size, shape, and location in the cheese curd structure was investigated using confocal laser scanning microscopy (CLSM).

\section{MATERIALS AND METHODS}

Mozzarella cheese curd was obtained from a commercial manufacturer in Victoria, Australia. The curd was manufactured using the general steps outlined in Kindstedt et al., (1999) and was taken from the process directly after whey draining (curd $\mathrm{pH}$ 6.2). The $\mathrm{pH}$ was monitored until it decreased to $\mathrm{pH}$ 5.4, at which point the samples were prepared for testing and analysis. Curd was wrapped in plastic film and stored for $60 \mathrm{~min}$ at $4^{\circ} \mathrm{C}$ before testing.

\section{Compression and Stretching}

Biaxial compression. Cylindrical curd samples of $15 \mathrm{~mm}$ height and $60 \mathrm{~mm}$ diameter were cut. Compression was performed between the two parallel plates of a Universal Testing Machine (Instron Ltd., London, UK) fitted with a $10 \mathrm{kN}$ load cell. The curd samples were placed in a water bath at each test temperature for 10 min before compression.

The effect of compression rate was investigated by compressing the test samples to $50 \%$ of the original height at cross-head speeds of 50, 500 and $2000 \mathrm{~mm} /$ min at $65^{\circ} \mathrm{C}$. The effect of extent of compression was assessed on different samples by compressing the curd at $1000 \mathrm{~mm} / \mathrm{min}$ to 40,60 and $80 \%$ of the original height at $65^{\circ} \mathrm{C}$. The effect of the temperature of the curd during compression was investigated at 55,65 and $75^{\circ} \mathrm{C}$ at a compression rate of $1000 \mathrm{~mm} / \mathrm{min}$ to $50 \%$ of the original height.

After compression of the curd, the test samples were wrapped in plastic film and stored at $4^{\circ} \mathrm{C}$ until further analysis. The compression experiments were replicated five times on five blocks from a single vat of curd.

Tensile stretching. Dumbbell-shaped curd samples of $150 \mathrm{~mm}$ length and $25 \mathrm{~mm}$ center diameter were cut for tensile stretching tests. Tensile stretching was performed at different temperatures using a tension apparatus attached to a Universal Testing Machine (Instron Ltd., London, U.K.) fitted with a $1 \mathrm{kN}$ load 
Table 2. The effect of extent of biaxial compression on composition, free oil content, and milk fat globule microstructure of curd compressed at a rate of $1000 \mathrm{~mm} / \mathrm{min}$ at $65^{\circ} \mathrm{C}(\mathrm{n}=5)$.

\begin{tabular}{lcccc}
\hline & \multicolumn{3}{c}{ Compression extent (\% original height) } & \\
\cline { 2 - 3 } & 40 & 60 & 80 & Significance \\
\hline Moisture, \% & 42.6 & 42.5 & 42.8 & NS \\
Fat, \% & 24.1 & 24.2 & 23.6 & NS \\
Fat in dry matter, \% & 42.0 & 42.0 & 41.2 & NS \\
Protein, \% & 26.1 & 26.0 & 26.3 & NS \\
Free oil, \% of curd & 8.4 & 7.5 & 8.3 & NS \\
Free oil, \% of fat & 34.8 & 31.2 & 35.4 & NS \\
Cross-sectional area, $\mu \mathrm{m}^{2}$ & 46.7 & 37.3 & 43.5 & NS \\
Maximum diameter, $\mu \mathrm{m}$ & 7.7 & 6.9 & 7.3 & NS \\
Circularity & 0.63 & 0.61 & 0.62 & NS \\
Elongation factor & 1 & 1.4 & 1.74 & \\
\hline
\end{tabular}

${ }^{1}$ Elongation factor $=($ maximum diameter $) /($ minimum diameter $)$.

cell. The curd samples were placed in a water bath at the test temperatures for $10 \mathrm{~min}$ before stretching.

The effect of rate of tensile stretching was determined by stretching the curd to $3.2 \times$ the original length at cross-head speeds of 1000 and $2500 \mathrm{~mm} / \mathrm{min}$ at $60^{\circ} \mathrm{C}$. The effect of the extent of tensile stretching was determined by stretching the curd to $1.4 \times$ and $4.6 \times$ the original length at a cross-head speed of $1000 \mathrm{~mm} / \mathrm{min}$ at $60^{\circ} \mathrm{C}$.

The interaction of extent of tensile stretching and temperature was determined by stretching the curd $1.5 \times$ and $3.5 \times$ the original length at 55 and $75^{\circ} \mathrm{C}$ at a cross-head speed of $1000 \mathrm{~mm} / \mathrm{min}$. The stretching experiments were replicated four times.

\section{Milk Fat Globule Microstructure}

Samples of curd for microstructural analysis were taken as a longitudinal section (in the direction of the stretching of the curd). A thin slice $(10 \mathrm{~mm} \times 10 \mathrm{~mm})$ of approximately 1-mm thickness was cut from the curd at $4^{\circ} \mathrm{C}$ using a scalpel. The samples were stained by immersion for $2 \mathrm{~min}$ in a $0.1 \%$ solution of water-soluble rhodamine B fluorescent dye (Sigma Chemical Co., St. Louis, MO). Excess dye was washed off with distilled water. Lipid-soluble Nile Blue fluorescent dye (Sigma Chemical Co.) was then directly applied in solid form to the surface of the cheese. Both of these dyes were used concurrently to observe the fat and aqueous phases of the cheese. The sample preparation procedure was performed over ice to keep the temperature low and minimize fat globule distortion.

The curd samples were observed using CLSM (Leica, Heidelberg, Germany), with an argon/krypton laser in dual-beam fluorescent mode, and excitation wavelengths of 647 and $568 \mathrm{~nm}$ for fat and aqueous phase, respectively. The fat globule size, shape, and location in the curd structure were determined from the micro- scope images using Image Tool for Windows version 2.0 (University of Texas Health Science Center, San Antonio, TX). The two-dimensional images had a resolution of $512 \times 512$ pixels and the pixel scale values were converted into micrometers using a scaling factor. Fat globules extending outside the area of the image were not analyzed. The maximum cross-sectional diameter, cross-sectional area, elongation (equal to the maximum diameter divided by the minimum cross-sectional diameter) and circularity of the globules were reported as number-weighted mean values (Everett et al., 1995). A circularity of one indicates a perfectly circular fat globule. Lower values tending toward zero indicate an increasing degree of distortion of the globules.

\section{Compositional Analysis and Free Oil}

One day after manufacture the curd samples were taken from refrigerated storage $\left(4^{\circ} \mathrm{C}\right)$ and prepared for free oil and compositional analyses. The curd was cut into $2 \mathrm{~cm}$ cubes, mixed and shredded using a food processor (Moulinex, Paris, France). The moisture, fat, and protein contents were determined using near infra-red spectroscopy (Infralab, TM5000E, Infrared Engineering, Irwindale, CA). Calibration curves were composed for Mozzarella cheeses encompassing a wide range of moisture, fat and protein contents, and used to determine the composition of the experimental curd samples. A reference sample was used with each measurement. Analysis of the protein (as nitrogen) and fat content of the reference and calibration samples was done by standard techniques (IDF, 1993; 1996). The moisture contents of the reference and calibration samples were determined gravimetrically at $105^{\circ} \mathrm{C}$ for 16 $\mathrm{h}$ in duplicate. The free oil content was measured by heating $9 \mathrm{~g}$ of shredded curd in a Babcock flask (Kindstedt and Rippe, 1990), and expressed as a percentage of total fat and of total curd weight. 
Table 3. The effect of tensile stretching rate on composition, free oil content, and milk fat globule microstructure of curd stretched to 3.2 times the original length at $60^{\circ} \mathrm{C}(\mathrm{n}=4)$.

\begin{tabular}{lccc}
\hline & \multicolumn{2}{c}{$\begin{array}{c}\text { Tensile stretching rate } \\
(\mathrm{mm} / \mathrm{min})\end{array}$} & \\
\cline { 2 - 3 } & 1000 & 2500 & Significance \\
\hline Moisture, \% & 43.1 & 42.9 & $\mathrm{NS}$ \\
Fat, \% & 23.8 & 24.0 & $\mathrm{NS}$ \\
Fat in dry matter, \% & 41.7 & 42.1 & $\mathrm{NS}$ \\
Protein, \% & 25.8 & 25.7 & $\mathrm{NS}$ \\
Free oil, \% of curd & 7.9 & 7.8 & $\mathrm{NS}$ \\
Free oil, \% of fat & 33.4 & 32.4 & $\mathrm{NS}$ \\
Cross-sectional area, $\mu \mathrm{m}^{2}$ & 37.1 & 32.1 & $\mathrm{NS}$ \\
Maximum diameter, $\mu \mathrm{m}$ & 6.0 & 6.1 & $\mathrm{NS}$ \\
Circularity & 0.53 & 0.50 & $\mathrm{NS}$ \\
Elongation factor ${ }^{1}$ & $1.91^{\mathrm{a}}$ & $2.61^{\mathrm{b}}$ & $*$ \\
\hline a,b & Subcolumn means within row and treatment category with different superscripts differ $(P<0.05)$. \\
${ }^{1}$ Elongation factor $=$ (maximum diameter)/(minimum diameter). & \\
$* P<0.05$. & &
\end{tabular}

\section{Statistical Analysis}

A randomized block design was used to evaluate the effect of the treatments on the dependent variables using SPSS 8.0 for Windows (SPSS Inc., Chicago, IL). Statistical significance was determined at $P<0.05$. Bonferroni comparisons were used to analyze the differences between means.

\section{RESULTS AND DISCUSSION}

\section{Composition of Mozzarella Curd}

The composition of the Mozzarella curd was not affected by the rate of biaxial compression (Table 1), the extent to which the curd was compressed (Table 2) or the rate of tensile stretching (Table 3 ) under the conditions tested. Therefore, in the present study, any changes in free oil formation when the curd was compressed cannot be attributed to differences in curd composition.

Curd that was stretched to 4.6 times its original length had a moisture content of $41.5 \%$, which was significantly lower $(P<0.05)$ than the $42.5 \%$ moisture content of the curd stretched $1.4 \times$ (Table 4$)$. The lower moisture content may be due to an increase in the surface area exposed to the atmosphere during stretching. The fat content of curd that was stretched to $4.6 \times$ its original length was $26.2 \%$, which was significantly higher $(P<0.05)$ than the curd stretched $1.4 \times$, with a fat content of $25.0 \%$ (Table 4 ). This difference may have been due to variations occurring during the cheese manufacturing process and was not considered to be of practical importance.

There were no significant differences in the composition of curd subjected to stretching water temperatures between 55 and $75^{\circ} \mathrm{C}$ (Table 5), and no effect of stretching water temperature in combination with extent of stretching (Table 6). Therefore, in these experiments, any effect on free oil formation when the curd was stretched cannot be attributed to differences in composition of the curd.

\section{Free Oil Formation}

The formation of free oil in the Mozzarella curd was not significantly affected by the rate of biaxial compression from 50 to $2000 \mathrm{~mm} / \mathrm{min}$ (Table 1), the extent of biaxial compression from 40 to $80 \%$ of the original height (Table 2), or the rate of tensile stretching from 1000 to $2500 \mathrm{~mm} / \mathrm{min}$ (Table 3). Increasing the extent to which the curd was stretched at a constant stretching rate of $1000 \mathrm{~mm} / \mathrm{min}$ significantly increased the free oil content of curd $(P<0.01)$ from $23.8 \%$ (for curd stretched to $1.4 \times$ its original length) to $32.3 \%$ (stretched to $4.6 \times$ ) based on the percentage of fat in cheese (Table 4). It must be noted, however, that the fat in dry matter also increases (Table 4) and this may increase the amount of free oil formed (Tunick, 1994).

Increasing the rate of stretching of curd using a screw mechanism will reduce the amount of free oil formed and decrease the meltability; however, there is no effect on apparent viscosity (Renda et al., 1997). The stretching rates in these studies are probably far higher than those achieved in this present study. Reducing the screw speed has been shown to increase the amount of free oil (Renda et al., 1997); however, curd stretched at the lower speed had a higher fat in dry matter which most likely contributed significantly to the formation of free oil.

Increasing the temperature of the cooking-stretching water had the effect of increasing the free oil content 
Table 4. The effect of extent of tensile stretching on composition, free oil content, and milk fat globule microstructure of curd stretched at a tensile rate of $1000 \mathrm{~mm} / \mathrm{min}$ at $60^{\circ} \mathrm{C}(\mathrm{n}=4)$.

\begin{tabular}{lccc}
\hline & \multicolumn{2}{c}{$\begin{array}{c}\text { Tensile stretching } \\
\text { (× original height) }\end{array}$} & \\
\cline { 2 - 3 } & 1.4 & 4.6 & Significance \\
\hline Moisture, \% & $42.5^{\mathrm{a}}$ & $41.5^{\mathrm{b}}$ & $*$ \\
Fat, \% & $25.0^{\mathrm{a}}$ & $26.2^{\mathrm{b}}$ & $*$ \\
Fat in dry matter, $\%$ & $43.1^{\mathrm{a}}$ & $44.7^{\mathrm{b}}$ & $*$ \\
Protein, \% & 26.2 & 25.8 & $\mathrm{NS}$ \\
Free oil, \% of curd & $5.9^{\mathrm{a}}$ & $8.6^{\mathrm{b}}$ & $* *$ \\
Free oil, \% of fat & $23.8^{\mathrm{a}}$ & $32.3^{\mathrm{b}}$ & $* *$ \\
Cross-sectional area, $\mu \mathrm{m}^{2}$ & 38.0 & 33.1 & $\mathrm{NS}$ \\
Maximum diameter, $\mu \mathrm{m}$ & 7.3 & 7.2 & $\mathrm{NS}$ \\
Circularity & 0.63 & 0.59 & $\mathrm{NS}$ \\
Elongation factor & $1.81^{\mathrm{a}}$ & $2.11^{\mathrm{b}}$ & $* *$ \\
\hline
\end{tabular}

${ }^{\mathrm{a}, \mathrm{b}}$ Subcolumn means within row and treatment category with different superscripts differ $(P<0.05)$.

${ }^{1}$ Elongation factor $=($ maximum diameter $) /($ minimum diameter $)$.

$* P<0.05$.

$* * P<0.01$.

$(P<0.001)$ from $24.1 \%$ when the stretching water was $55^{\circ} \mathrm{C}$, to $34.5 \%$ at $75^{\circ} \mathrm{C}$ for curd compressed to $50 \%$ of its original height at $1000 \mathrm{~mm} / \mathrm{min}$ (Table 5). The increase in free oil may be due to larger fat globules, as shown by the higher cross-sectional area and maximum diameter. A higher cooking temperature will cause the protein matrix to become less elastic (Mulvaney et al., 1997), thus more flowable, allowing fat to coalesce into larger pools upon stretching that may contribute to free oil formation. More highly emulsified, and thus smaller, fat globules indicate less coalescence has taken place, producing less free oil (Paquet and Kalab, 1988; Tunick, 1994). The rheological behavior of the protein matrix may be the major factor affecting fat globule microstructure and free oil formation, and this is probably most affected by curd temperature at the cooking and stretching stage.
Both the extent of tensile stretching and the temperature of the cooking-stretching water had a significant effect on free oil formation. These two parameters were combined in a $2 \times 2$ factorial experiment to determine if there was any interaction between these parameters. As in the previous experiments where the factors were examined individually, increasing the length of tensile stretching (from $1.5 \times$ to $3.5 \times$ ) and the temperature of the stretching water (from 55 to $75^{\circ} \mathrm{C}$ ) both significantly increased the free oil formation from the curd (Table 6). However, there was no significant interaction between these two parameters under the conditions used.

The strains and stresses found in a Mozzarella cooker-stretcher are difficult to quantify. The strains imposed during biaxial compression are lower than that occurring during tensile stretching in this study, which

Table 5. The effect of temperature of stretching water on composition, free oil content, and milk fat globule microstructure of curd compressed to $50 \%$ of the original height at a tensile rate of $1000 \mathrm{~mm} / \mathrm{min}(\mathrm{n}=4)$.

\begin{tabular}{lcccc}
\hline & \multicolumn{3}{c}{ Temperature of stretch water $\left({ }^{\circ} \mathrm{C}\right)$} & \\
\cline { 2 - 4 } & 55 & 65 & 75 & Significance \\
\hline Moisture, \% & 41.5 & 41.2 & 41.4 & NS \\
Fat, \% & 25.7 & 26.1 & 25.8 & NS \\
Fat in dry matter, \% & 43.9 & 44.5 & 43.9 & NS \\
Protein, \% & 26.0 & 25.9 & 25.6 & NS \\
Free oil, \% of curd & $6.2^{\mathrm{a}}$ & $7.8^{\mathrm{b}}$ & $8.9^{\mathrm{c}}$ & $* * *$ \\
Free oil, \% of fat & $24.1^{\mathrm{a}}$ & $29.8^{\mathrm{b}}$ & $34.5^{\mathrm{c}}$ & $* * *$ \\
Cross-sectional area, $\mu \mathrm{m}^{2}$ & $26.0^{\mathrm{ab}}$ & $32.0^{\mathrm{b}}$ & $45.7^{\mathrm{c}}$ & $* *$ \\
Maximum diameter, $\mu \mathrm{m}$ & $6.1^{\mathrm{a}}$ & $6.6^{\mathrm{a}}$ & $7.3^{\mathrm{b}}$ & $* *$ \\
Circularity & 0.56 & 0.55 & 0.59 & $\mathrm{NS}$ \\
Elongation factor & 1.05 & 1.41 & 1.77 & $\mathrm{NS}$ \\
\hline
\end{tabular}

${ }^{\mathrm{a}, \mathrm{b}, \mathrm{c}}$ Subcolumn means within row and treatment category with different superscripts differ $(P<0.05)$.

${ }^{1}$ Elongation factor $=($ maximum diameter $) /($ minimum diameter $)$.

$* * P<0.01$.

$* * * P<0.001$. 
Table 6. The effect of stretching length and temperature on composition, free oil content, and milk fat globule microstructure of curd stretched at a tensile rate of $1000 \mathrm{~mm} / \mathrm{min}(\mathrm{n}=4)$.

\begin{tabular}{|c|c|c|c|c|c|c|c|}
\hline & \multicolumn{4}{|c|}{ Temperature $\left({ }^{\circ} \mathrm{C}\right)$} & & & \\
\hline & \multicolumn{2}{|c|}{55} & \multicolumn{2}{|c|}{75} & & & \\
\hline & \multicolumn{4}{|c|}{ Stretching extent ( $\times$ original length) } & \multicolumn{3}{|c|}{ Significance } \\
\hline & 1.5 & 3.5 & 1.5 & 3.5 & $\mathrm{~T}^{1}$ & $\mathrm{~S}^{2}$ & $\mathrm{~T} \times \mathrm{S}^{3}$ \\
\hline Moisture, \% & 42.3 & 42.5 & 42.3 & 42.4 & NS & NS & NS \\
\hline Fat, $\%$ & 24.4 & 24.2 & 24.3 & 24.4 & NS & NS & NS \\
\hline Fat in dry matter, $\%$ & 42.3 & 43.0 & 42.1 & 42.1 & NS & NS & NS \\
\hline Protein, \% & 26.0 & 26.0 & 25.7 & 25.6 & NS & NS & NS \\
\hline Free oil, $\%$ of curd & $7.7^{\mathrm{a}}$ & $8.4^{\mathrm{b}}$ & $8.1^{\mathrm{c}}$ & $9.1^{\mathrm{d}}$ & $*$ & $*$ & NS \\
\hline Free oil, $\%$ of fat & $31.8^{\mathrm{a}}$ & $34.7^{\mathrm{b}}$ & $33.4^{\mathrm{c}}$ & $37.4^{\mathrm{d}}$ & $* *$ & $* *$ & NS \\
\hline Cross-sectional area, $\mu \mathrm{m}^{2}$ & $48.8^{\mathrm{a}}$ & $97.4^{\mathrm{b}}$ & $54.0^{\mathrm{a}}$ & $88.1^{b}$ & $* *$ & NS & NS \\
\hline Maximum diameter, $\mu \mathrm{m}$ & $7.2^{\mathrm{a}}$ & $10.4^{b}$ & $7.9^{\mathrm{a}}$ & $9.7^{\mathrm{b}}$ & $* *$ & NS & NS \\
\hline Circularity & 0.71 & 0.68 & 0.71 & 0.70 & NS & NS & NS \\
\hline Elongation factor ${ }^{4}$ & 1.60 & 1.65 & 1.83 & 1.62 & NS & NS & NS \\
\hline
\end{tabular}

may explain the lack of effect on free oil by the extent and rate of compression.

\section{Milk Fat Globule Microstructure}

The size, shape, and location of milk fat globules in the curd were examined using CLSM after stretching or compressing the curd. Increasing the rate of biaxial compression from 50 to $2000 \mathrm{~mm} / \mathrm{min}$ decreased the elongation factor of the milk fat globules from 1.90 to $1.75(P<0.01)$. There was no decrease from 50 to 500 $\mathrm{mm} / \mathrm{min}$ (Table 1 ). Interestingly, there was no corresponding effect on the formation of free oil. The decrease in the elongation factor may have been too small to affect free oil formation. Cross-sectional area, maximum diameter, and circularity were not affected by the rate of biaxial compression (Table 1). The extent to which the curd was compressed had no effect on the milk fat globule size and shape parameters (Table 2).

Increasing the tensile stretching rate from 1000 to $2500 \mathrm{~mm} / \mathrm{min}$ increased $(P<0.05)$ the elongation factor from 1.91 to 2.61 but there was no corresponding increase in free oil formation (Table 3). Increasing the extent to which the cheese curd was stretched (from $1.4 \times$ to $4.6 \times)$ significantly increased $(P<0.01)$ the elongation factor of the milk fat globule, but did not affect any of the other fat globule parameters measured (Table 4). In this case, the increase in elongation factor corresponded to a significant increase $(P<0.01)$ in free oil formation. It is concluded that an increase in the extent to which the curd was stretched caused a rupturing of the milk fat globule membrane and some coalescence of globules, accounting for the increase in free oil. This is most likely concomitant with elongation of pools of fat within the curd structure (Taneya et al., 1992). The increase in free oil upon stretching evidently does not occur when the rate of tensile stretching changes, where the globule membranes most likely remain intact. Membrane rupture was not directly measured, but a change in the shape of the globules was observed in the CLSM micrographs (Figures 1 and 2), indicating that rupturing may have taken place.

When the temperature of the stretching water was increased from 55 to $75^{\circ} \mathrm{C}$ there was a significant increase $(P<0.01)$ in the cross-sectional area and maximum diameter of the milk fat globules (Table 5). The increase in free oil observed at the $75^{\circ} \mathrm{C}$ cooking-stretching temperature may be due to larger pools of coalesced fat at this elevated temperature. Melted pools of fat have been observed within serum channels in curd that has been stretched in hot water (Kiely et al, 1992). An increase in the milk fat globule size at higher cook temperatures is shown in the CLSM micrographs (Figures 3 and 4) where the globules in curd compressed to $50 \%$ height at $1000 \mathrm{~mm} / \mathrm{min}$ at $75^{\circ} \mathrm{C}$ are visibly larger than for curd compressed at $55^{\circ} \mathrm{C}$. The observed changes in the milk fat globules may be a result of the milk fat melting more rapidly at the elevated temperature, or to the coalescence of neighboring milk fat globules facilitated by the compression process. Interest- 


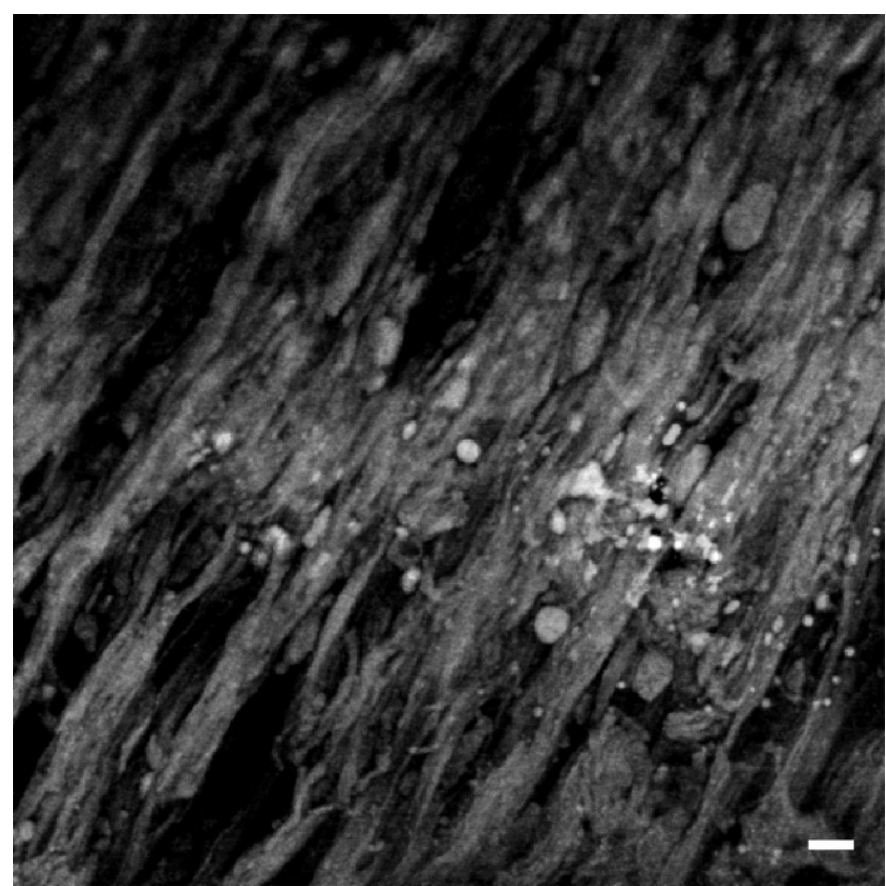

Figure 1. Confocal laser scanning micrograph of Mozzarella curd stretched to 4.6 times its original length at $1000 \mathrm{~mm} / \mathrm{min}$ at $60^{\circ} \mathrm{C}$. Fat is shown as a lighter shade of gray. Scale bar is $10 \mu \mathrm{m}$.

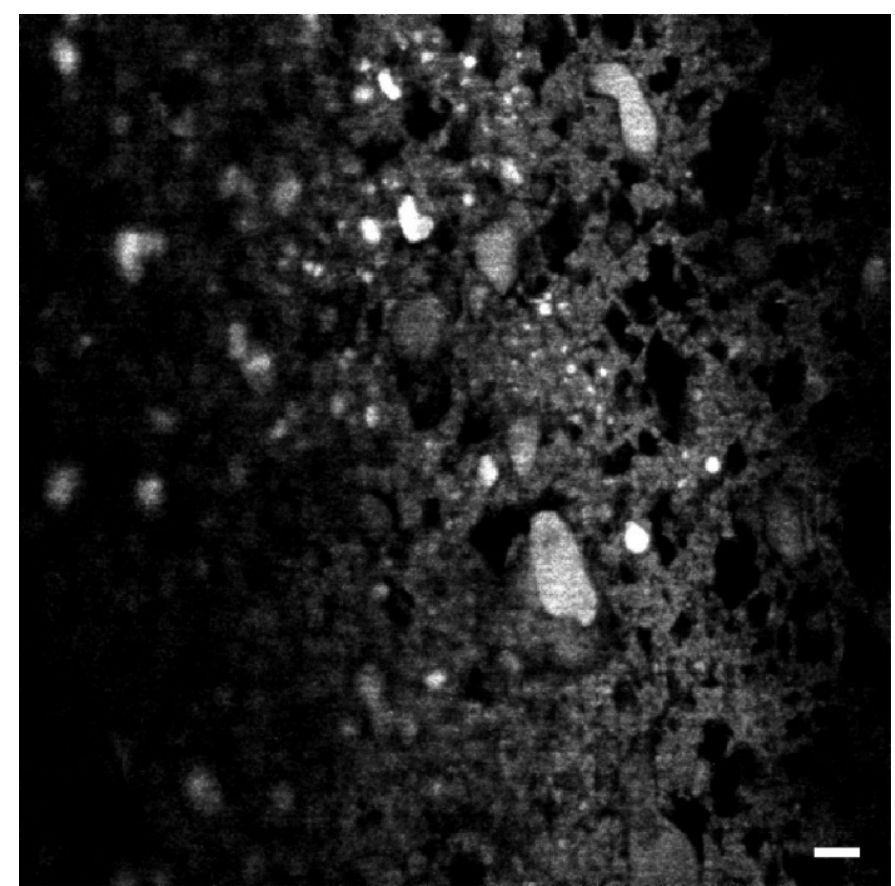

Figure 3. Confocal laser scanning micrograph of Mozzarella curd compressed to $50 \%$ height at $1000 \mathrm{~mm} / \mathrm{min}$ at $55^{\circ} \mathrm{C}$. Fat is shown as a lighter shade of gray. Scale bar is $10 \mu \mathrm{m}$.

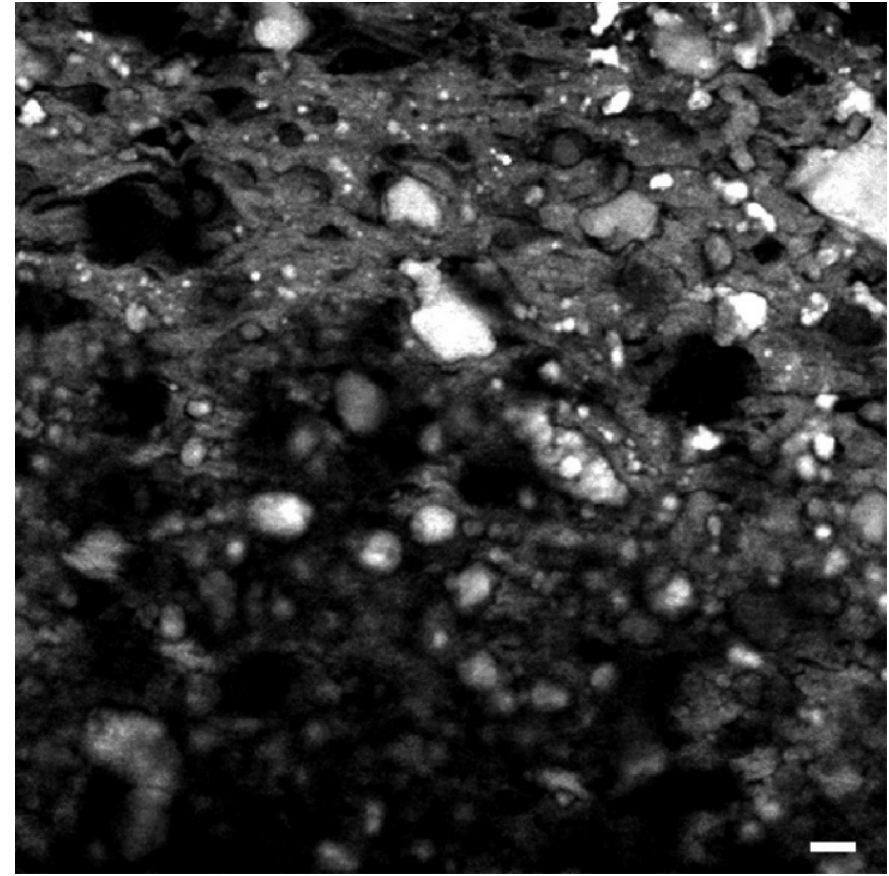

Figure 2. Confocal laser scanning micrograph of Mozzarella curd stretched 1.4 times its original length at $1000 \mathrm{~mm} / \mathrm{min}$ at $60^{\circ} \mathrm{C}$. Fat is shown as a lighter shade of gray. Scale bar is $10 \mu \mathrm{m}$.

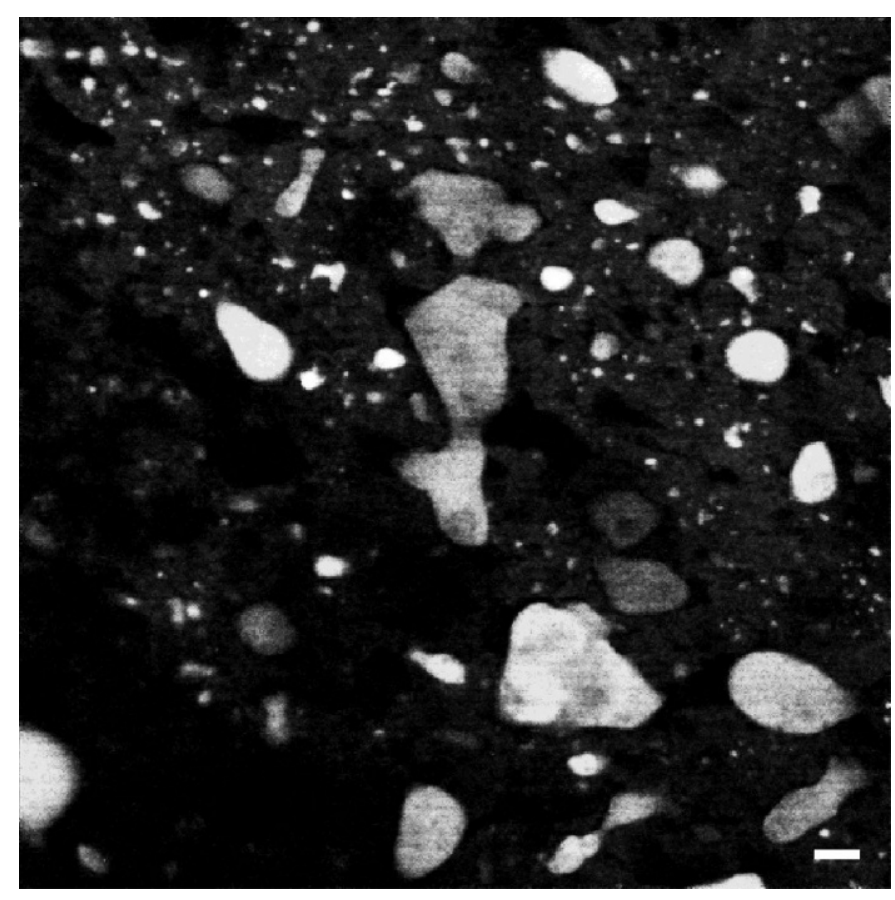

Figure 4. Confocal laser scanning micrograph of Mozzarella curd compressed to $50 \%$ height at $1000 \mathrm{~mm} / \mathrm{min}$ at $75^{\circ} \mathrm{C}$. Fat is shown as a lighter shade of gray. Scale bar is $10 \mu \mathrm{m}$. 
ingly, there was no change in circularity or elongation factor of fat globules at the higher temperatures. Fat that contributes to free oil formation in this case may exist as large pools held within the protein matrix of the curd formed by globule coalescence, rather than partially ruptured and distorted individual globules.

The factorial experiment investigating the interaction between the temperature of the stretching water and the extent of tensile stretching confirmed that increasing the extent of stretching at both temperatures significantly increased both the milk fat globule crosssectional area and the maximum diameter $(P<0.01)$, as well as the amount of free oil (Table 6). This was also shown in Table 5. There was no significant effect on circularity or elongation factor by either temperature or extent of stretching. The extent of stretching (3.5 $\times)$ may not have been sufficient to increase the elongation factor of fat globules in this case, compared with stretching to the greater extent of $4.6 \times$ as shown in Table 4 .

\section{CONCLUSIONS}

The effects of the extent and rate of stretching and compression, and the cooking-stretching temperature on the size and shape of fat globules and on free oil formation were investigated. Increasing the temperature of the cooking-stretching water resulted in an increase in the milk fat globule size and an increase in free oil content, indicating that the melting and coalescence of milk fat globules during the cooking and stretching process is one determinant of the amount of free oil in Mozzarella curd. Compression did not significantly affect the amount of free oil formed in the Mozzarella curd at the rates and extents imposed; however, extent of tensile stretching did significantly affect the amount of free oil formed. Stretching the curd by $4.6 \times$ the original length resulted in a significantly larger amount of free oil compared to that in curd stretched $1.4 \times$. The milk fat globule size was not affected by the degree of stretching, but an increase in extent and rate of stretching resulted in elongation of the globules. These results indicate a second determinant in free oil formation, that stretching of curd may result in rupturing of the milk fat globule membrane with a concomitant increase in free oil.

\section{ACKNOWLEDGMENTS}

This research was funded by a grant from the Dairy Research and Development Corporation, Melbourne, Australia.

\section{REFERENCES}

Apostolopoulos, C., V. E. Bines, and R. J. Marshall. 1994. Effect of post-cheddaring manufacturing parameters on the meltability and free oil of Mozzarella cheese. J. Soc. Dairy Technol. 47:84-87.

Everett, D. W., K. Ding, N. F. Olson, and S. Gunasekaran. 1995. Applications of confocal microscopy to fat globule structure in cheese. Pages 321-330 in Chemistry of Structure/Function Relationships in Cheese. E. L. Malin and M. H. Tunick, eds. Plenum Press, New York, NY.

IDF. 1993. Determination of nitrogen content. Rep. No. 20B:1993, IDF, Brussels, Belgium.

IDF. 1996. Determination of fat content. Rose-Gottlieb Gravimetric method. Rep. No. 1D:1996, IDF, Brussels, Belgium.

Kiely, L. J., P. S. Kindstedt, G. M. Hendricks, J. E. Levis, J. J. Yun, and D. M. Barbano. 1992. Effect of draw pH on the development of curd structure during the manufacture of Mozzarella cheese. Food Struct. 11:217-224.

Kindstedt, P. S., and M. R. Guo. 1998. A physico-chemical approach to the structure and function of Mozzarella cheese. Aust. J. Dairy Technol. 53:70-73.

Kindstedt, P. S., and J. K. Rippe. 1990. Rapid quantitative test for free oil (oiling off) in melted Mozzarella cheese. J. Dairy Sci. 73:867-873.

Kindstedt, P. S., M. Rowney, and P. Roupas. 1999. Technology, biochemistry and functionality of pasta filata/pizza cheese. Pages 193-221 in Technology of Cheesemaking. B. A. Law, ed. Academic Press, Sheffield, UK.

McMahon, D. J., C. J. Oberg, and W. McManus. 1993. Functionality of Mozzarella cheese. Aust. J. Dairy Technol. 48:99-104.

Mulvaney, S., S. Rong, D. M. Barbano, and J. J. Yun. 1997. Systems analysis of the plasticization and extrusion processing of Mozzarella cheese. J. Dairy Sci. 80:3030-3039.

Oberg, C. J., W. R. McManus, and D. J. McMahon. 1993. Microstructure of Mozzarella cheese during manufacture. Food Struct. $12: 251-258$

Paquet, A., and M. Kalab. 1988. Amino acid composition and structure of cheese baked as a pizza ingredient in conventional and microwave ovens. Food Microstruct. 7:93-103.

Renda, A., D. M. Barbano, J. J. Yun, P. S. Kindstedt, and S. J. Mulvaney. 1997. Influence of screw speeds on the mixer at low temperature on characteristics of Mozzarella cheese. J. Dairy Sci. 80:1901-1907.

Taneya, S., T. Izutsu, T. Kimura, and T. Shioya. 1992. Structure and rheology of string cheese. Food Struct. 11:61-71.

Tunick, M. H. 1994. Effects of homogenization and proteolysis on free oil in Mozzarella cheese. J. Dairy Sci. 77:2487-2493.

Yun, J. J., L. J. Kiely, P. S. Kindstedt, and D. M. Barbano. 1993. Mozzarella cheese: impact of milling $\mathrm{pH}$ on functional properties. J. Dairy Sci. 76:3639-3647. 